\title{
Key performance indicators of management consulting
}

\author{
Aygul Z. Ibatova ${ }^{a^{*}}$, Valentina I. Kuzmenko ${ }^{b}$ and G. S. Klychova ${ }^{c}$ \\ ${ }^{a}$ Tyumen Industrial University, Russia \\ ${ }^{b}$ Elabuga Institute (branch) of Kazan (Volga Region) Federal University, Russia \\ ${ }^{c}$ Kazan Federal University, Institute of Management, Economics and Finance, Kazan, Russia \\ CHRON I C L E ABSTRACT
}

Article history:

Received: November 26, 2017

Received in revised format: January 31,2018

Accepted: March 29, 2018

Available online:

March 29, 2018

Keywords:

Key indicators of efficiency

Methodological tools

Management

Management consulting

\begin{abstract}
The developing theoretical managerial concepts and applied managerial techniques comprise the basis for the modern innovative management of an agricultural enterprise. Management consulting occupies a special place in the managerial process. It is aimed at rendering experts' support to the specialists of an economic entity as well as developing recommendations for the promotion of activity efficiency in the enterprise on the basis of theoretical and applied knowledge in the field of management. Complicated conditions for activity carried out by the Russian agricultural commodities manufacturers cause the necessity in the real managerial activity integration with the scientific research works in the field of management. Hence, the necessity occurs in professional management consulting by considering technological features of the production process and the scientific basics of management. This article considers the economic essence of management consulting, offers a conceptual model and methodological instruments, and develops the system of key indicators of social-economic activity efficiency as an instrument of management consulting.
\end{abstract}

\section{Introduction}

The current state of management consulting as one of the professional activity types is characterized by the emergence of innovative management procedures, methods and tools, which are construed as one of the competitive advantages types and the main factor contributing to the strategic, tactical and operational activity effectiveness. At the same time, there is a certain terminological discrepancy between the framework of categories, insufficiently substantiated structuring of key components, and an uncertain relationship with other economic sciences in management consulting as a field of scientific knowledge. In this connection, there occurs a necessity in the development and justification the conceptual foundations for management consulting that could correspond to the current trends in the development of economic science. The following main typical features for management consulting are distinguished in the literature: management consulting is aimed at introducing certain changes in the structure of financial and economic activity of the organization; management consulting is carried out by highly qualified specialists in conjunction with the management of the organization; management consulting is aimed at improving the organization efficiency; management consulting is characterized 
by a complex nature consisting of various activity lines of the organization transformation (Kolbina et al., 2016). Management consulting is a set of interrelated procedures aimed at providing professional support to the company management in strategic development for achievement of competitive advantages and in solving managerial and production issues in conditions of limited resources and uncertainty of economic situations, as well as taking into account the measures for their practical implementation based on the analysis of economic data on its internal and external environment. One should distinguish strategic, tactical and operational consulting depending on the objectives pursued by management consultants, rendering assistance to the business leaders in the process of developing systemic and integrated solutions to the issues connected with management organization of complex systems in different areas of activity. Strategic management consulting is aimed at providing consulting assistance to the company management in assessing the external environment in order to find and effectively use the internal opportunities in achieving a sustainable competitiveness of the enterprise in the long term perspective. Tactical management consulting is designed to provide in consulting support in identifying means enabling business leaders to transform their strategic plans, goals and decisions into activities of the executive staff. Operation management consulting is based on the information feedback property and is aimed at creating conditions for rapid response of managers to significant deviations of the actual data from the planned one.

\section{Methodology}

When formulating a conceptual model, it is necessary to formulate properly, identify system-forming elements and develop practical implementation techniques aimed at improvement the efficiency of the company operation, including its purpose, functions, tasks, object, subject, methods, principles and tools (Salimon et al., 2017).

The proposed model highlights, conceptually specifies and structures elements forming theoretical basis of the modern concept of management counseling (Fig. 1). The objective of management consulting, in accordance with the author's concept, is to conduct certain consulting, analytical and research work related to the substantiation of development prospects and application of organizational, economic, scientific, technical and methodological innovations, taking into account the needs of the economy and the management of commercial and non-profit organizations, regardless of their size, organizational and legal form and industry affiliation.

The main tasks of management consulting are defined in the above description as follows:

- forecasting and analysis of environmental conditions affecting the enterprise operation, with the purpose of selecting, implementing and evaluating the efficiency of the enterprise's competitive development strategy (Gorman \& McCarthy, 2006; Klychova et al., 2017);

- evaluating the internal processes and resources of the enterprise, which form its potential, for exercising control and increasing the efficiency of their use (Huning et al., 2011);

- providing of certain methods and tools to the client for carrying out organizational diagnostics of the company's state, solving the identified problems, elaborating strategic plans for the organization development (Klychova et al., 2017; Kalenskaya \& Shafigullina, 2014);

- rendering assistance in acquiring special knowledge (in particular, in forecasting of economic situation, situation analysis), mastering methods used in the process of identifying problems and implementing changes (the so-called training consulting).

Goals and objectives of management consulting determine its functions. The following functions of management consulting can be distinguished: analytical; planning-forecasting; consulting; controlling; coordinating. 
One of the key elements of the management consulting system is the integrity of its matter, objects, subjects and their interrelation. The object of management consulting is the object of management as a special type of labor activity. The subject of management consulting is a management consultant or a management consulting specialist with special knowledge and practical skills who fulfills the activity of the client's company performance improvement (Klychova et al., 2014b; Klychova et al., 2014a).

The matter of management consulting is the method of introducing managerial and economic knowledge into the company practical activity. The main specific matter of consultation is the process of production and sales of products, the so-called "consulting service".

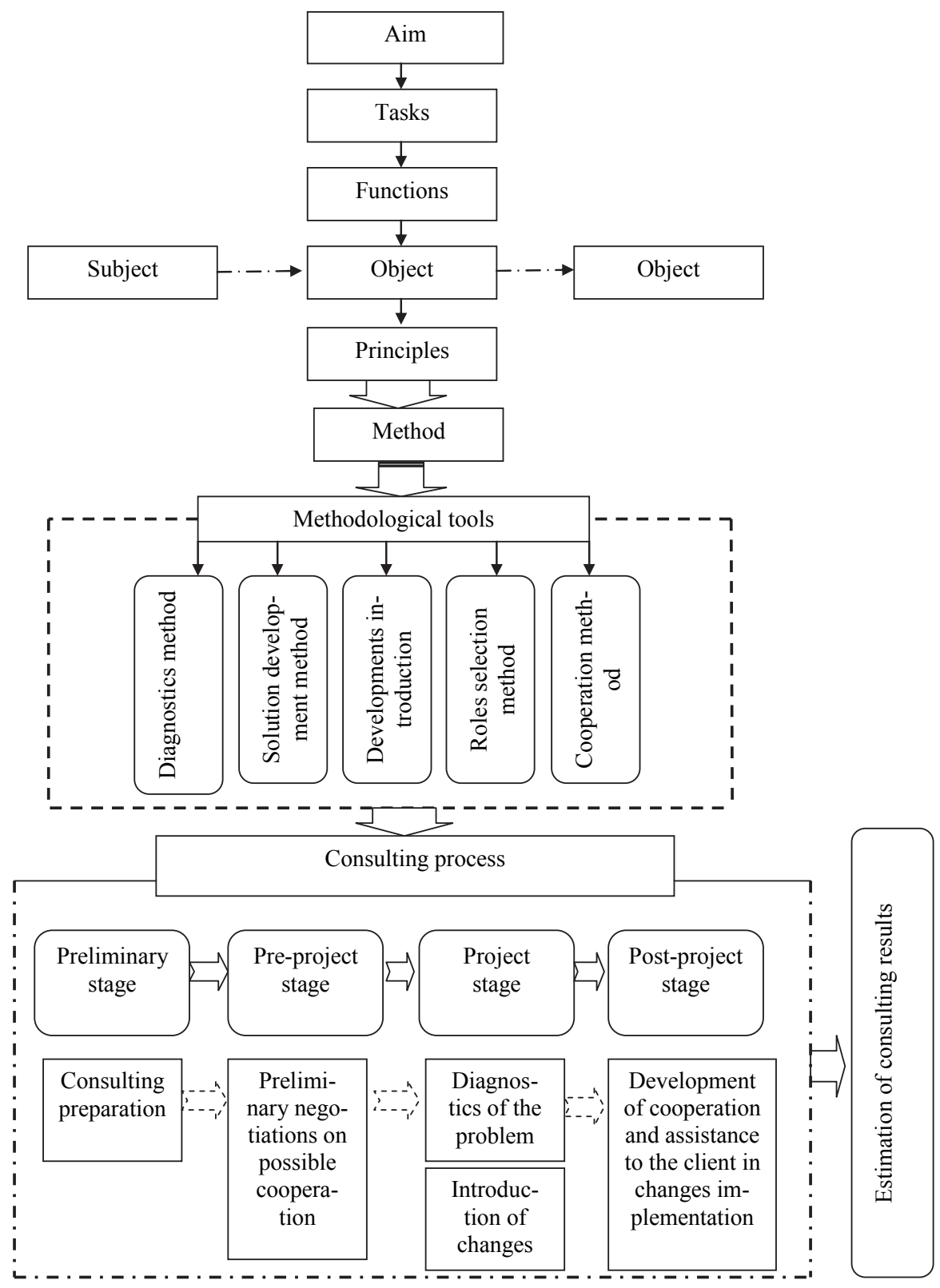

Fig. 1. Conceptual model of management consulting

The consultant's activity is based on the initial provisions of management consulting, which are enshrined in its principles. Moreover, it should be noted that, depending on the management consulting 
directions at different time levels, the consultants may be subject to additional requirements that act as particular principles. Thus, the principles of management consulting are as follows: legitimacy; scientific character; sustainability; flexibility; dynamism; professional competence; timeliness; safety of the system; upgrading ability; responsibility; efficiency.

The modern system of management consulting uses various tools and methods, both private and borrowed, integrating them depending on the tasks to be accomplished.

Based on the conceptual approaches to management consulting, each company forms a separate methodological toolkit providing assistance to the head of the client organization in diagnosing, analyzing and settlement of practical production and management problems. Methodological tool of management consulting represents a complex mechanism for integration and coordination of individual tools, the variable application of which contributes to the achievement of the set goals (Klychova et al., 2015c; Klychova et al., 2015a; 2015b). The tool is a means of practical implementation of its methods.

In accordance with the above conceptual model of management consulting, the following groups of methods can be distinguished: diagnostic methods, methods of problem solution, method of developments implementation, method of the roles for a consultant and a client selection, methods of cooperation and assisting a client in changes implementation (Boeger et al., 2008).

In the process of consulting, the consultant performs joint activities with managers and specialists of a client's organization. Efficient approach to organization of management consulting affects the efficiency of the resources application, as well as the achievement of necessary results, the quality of the expected changes, and further successful cooperation of the parties. The consultation process includes the following stages:

- The preliminary stage is based on the awareness on the part of the company management team of the problems existence and the need in their resolving through the outside consultant. This stage is dedicated to collecting and analyzing information on consultants, their services, and cooperation conditions;

- Pre-project stage. At this stage, negotiations are held between a consultant and a client-company on possible cooperation and possible ways of resolving them. At the pre-project stage, training and consulting activities (seminars, exhibitions, conferences) with the participation of future clients and consultants are effective;

- Project stage. At this stage, the consultants carry out diagnosing of the client's company, collect data and form a comprehensive picture of the organization's vital activity for analyzing data on the organizational, technical, financial and economic status, as well as prospects for the enterprise development (Safiullin et al., 2014c). The project phase is completed with the implementation phase;

- Post-project stage. At this stage, the completed work is evaluated, and the actual results are compared with the planned ones, deviations volume and the reasons for their occurrence are analyzed, additional corrective measures are carried out, a report is made on the fulfilled work and an acceptance - delivery certificate is signed.

After the completion of a specific task, the consultant and the client company can agree upon continuation of working relations. In particular, if the necessity of cooperation with the client prolongation is found in the process of the task performance assessment, the consultant may continue his work, as indicated in the final report. In addition, there may occur a need in identification and solution of new emerging issues in the company's production and financial activity. 


\section{Results}

One of the main reasons for using consulting in a company is the expected positive economic effect, as the client is interested in the quality of the result, but not the process of counseling. However, it should be borne in mind that the result obtained from the implementation of the consulted project can be under the influence not only of the consultant, but also of the client himself. In assessing the quality of the advisory work, the following factors are taken into account: macro and microenvironment as well as the specific situation in the company itself; qualification, personal experience, goals and motivations, personal qualities of the consultant; experience, worldview, personal qualities of the client.

It is advisable to apply a system of key performance indicators for evaluation of management consulting efficiency. At the present stage of economic reforms KPI (Key Performance Indicators) is one of the main tools for assessing the efficiency of production, elaborating a development strategy based on this assessment, monitoring and control of the employees business activity, of structural units and the enterprise as a whole (Lee et al., 2011). Using the Key Performance Indicators system, the current situation is analyzed in a strategic perspective, and each employee can objectively evaluate his contribution into the implementation of the company's development strategy. The KPI system, being a flexible management tool, can vary depending on the objectives of the enterprise. In modern production, in addition to determining the management personnel efficiency, KPI is used in the management of business processes. This is due to the fact that the KPI system includes direct indicators of efficiency, effectiveness, productivity of business processes (Strelnik et al., 2017).

The Key Performance Indicators allow us to establish the causal connections between the targets and the set parameters for determining the patterns and mutual factors of influence on financial and production activity, identifying the dependence of some indicators on the other ones (Nizamutdinov et al., 2014c; Klychova et al., 2015d). The development and the implementation of Key Performance Indicators system is caused by the need to ensure transparency and measurability of the business, and the opportunity for developing optimal management decisions (Rompho, 2011). The difficulty in assessing the advisory activity is that it is not always possible to clearly express quantitative results and determine the share of the consultant due to the influence of a number of factors on the consultation process. In this regard, we propose to evaluate the management consulting process in terms of the benefits received by the consultant and the client in four interrelated blocks: finance, market, business processes and employees with determination of their qualitative and quantitative component (Antonchenko \& Kalenskaya, 2014). In addition, in our opinion, in assessing the effectiveness of the management consulting it is necessary to take into account its social components. At the enterprises of the agro-industrial complex, the development and implementation of human resources, the formation of environmental sustainability and the implementation of socially significant projects form the basis of social efficiency (Teixeira, 2013). In the process of human resources development and realization, it is necessary to take into account the harmonious individual development of each employee's, his qualifications, flexibility and mobility, a favorable social climate, social activity and improvement of the whole way of life (Teixeira, 2013; Klychova et al., 2016; Klychova et al., 2017; Ibatova, 2017). These factors have a direct impact on the labor quality. Key indicators for assessing the development and realization of human resources are presented in Table 1. It is possible to draw conclusions about the effectiveness of management consulting upon comparing the key indicators before and after its performance. Thus, analyzing the data in Table 1, it will be possible to conclude that management consulting resulted in the increase in indicators characterizing the development and implementation of human resources, formation of environmental sustainability and the effectiveness of implementing socially significant projects. For example, the costs associated with retraining and qualification upgrading of one employee as well as the amount of additional social guarantees were increased by $7.2 \%$ and $6.7 \%$ respectively; the number of employees who passed retraining and qualification upgrading was increased by $11.8 \%$. 
Table 1

Indicators of development and realization of human resources assessment

\begin{tabular}{|c|c|c|c|c|}
\hline & Indicator & Calculation method & $\begin{array}{c}\text { Before carrying } \\
\text { out management } \\
\text { consulting }\end{array}$ & $\begin{array}{l}\text { After carrying } \\
\text { out management } \\
\text { consulting }\end{array}$ \\
\hline 1. & $\begin{array}{l}\text { Zzpklr } \\
\text { Costs for retraining and qualification up- } \\
\text { grading per one employee, thousand rub. } \\
\text { per one person. }\end{array}$ & $\begin{array}{l}\sum_{z p p k l r}=\sum_{z p p k} \div \mathrm{N} \\
\text { where, } \sum_{\text {zppk }}-\text { total costs for retraining and qualifi- } \\
\text { cation upgrading, thousand rub. } \\
\mathrm{N}-\text { number of employees in organization, people }\end{array}$ & 12,5 & 13,4 \\
\hline 2. & $\begin{array}{l}\sum \mathrm{N}_{\mathrm{ppk}} \\
\text { Number of employees, who passed retrain- } \\
\text { ing and qualification upgrading, people, in- } \\
\text { cluding: } \\
\text { workers } \\
\text { specialists } \\
\text { managers }\end{array}$ & $\begin{array}{l}\sum N_{\text {ppk }}=N_{\text {ppkr }}+N_{\text {ppks }}+N_{\text {ppkruk }} \\
N_{\text {ppkr }}-\text { Number of workers, who passed retraining } \\
\text { and qualification upgrading, people. } \\
\mathrm{N}_{\text {ppks }} \text { - Number of specialists, who passed retraining } \\
\text { and qualification upgrading, people } \\
\mathrm{N}_{\text {ppkruk }} \text { - Number of managers, who passed retrain- } \\
\text { ing and qualification upgrading, people }\end{array}$ & 34 & 38 \\
\hline 3. & $\begin{array}{l}\mathrm{HO}_{\text {lpers }} \\
\text { Number of training hours per one employee } \\
\text { hours per one person }\end{array}$ & $\begin{array}{l}\mathrm{HO}_{\text {lpers }}= \\
\left(\mathrm{HO}_{\text {tot }}-\mathrm{HO}_{\text {oblig }}\right) \mathrm{N} \\
\mathrm{HO}_{\text {total }}-\text { Number of training hours (internal exter- } \\
\text { nal) for the reporting period, hour } \\
\mathrm{HO}_{\text {oblig }} \text { Number of obligatory training hours for the } \\
\text { reporting period, hour } \\
\mathrm{N}-\text { number of employees in the company, people. }\end{array}$ & 24 & 32 \\
\hline 4. & $\begin{array}{l}\mathrm{Q}_{\mathrm{ppk}} \\
\text { Share of employees, who passed retraining } \\
\text { and qualification upgrading, in the total } \\
\text { number of employees, } \%\end{array}$ & $\begin{array}{l}\mathrm{Q}_{\mathrm{ppk}}=\mathrm{N}_{\mathrm{ppk}} \div \mathrm{N} \times 100 \% \\
\mathrm{~N}_{\mathrm{ppk}}-\text { Number of employees, who passed retraining } \\
\text { and qualification upgrading, people } \\
\mathrm{N} \text { - Number of employees in the company, people }\end{array}$ & 26 & 28 \\
\hline 5. & $\begin{array}{l}\mathrm{Q}_{\mathrm{sg}} \\
\text { Volume of additional social guarantees, } \\
\text { thousand rub. }\end{array}$ & $\begin{array}{l}\mathrm{Q}_{\mathrm{sg}}=\sum \mathrm{S}_{\mathrm{sg}} \\
\sum \mathrm{S}_{\mathrm{sg}}-\text { total amount of funds actually spent for, ad- } \\
\text { ditional social guarantees }\end{array}$ & 4582 & 4891 \\
\hline 6. & $\begin{array}{l}\mathrm{V}_{\text {ebpp }} \\
\text { Amount of funds allocated by the enterprise } \\
\text { for organization of environmentally safe } \\
\text { production activity, thousand rub. per pro- } \\
\text { duction unit }\end{array}$ & $\begin{array}{l}\mathrm{V}_{\text {ebpp }}=\sum \mathrm{Z}_{\text {ebpp }} \div \mathrm{q} \\
\sum \mathrm{Z}_{\text {ebpp }}-\text { amount of funds allocated by the enterprise } \\
\text { for organization of environmentally safe production } \\
\text { activity, thousand rub. } \\
\mathrm{q}-\text { volume of manufactured products }\end{array}$ & 18,6 & 20,4 \\
\hline 7. & $\begin{array}{l}V_{\text {ochs }} \\
\text { Amount of funds allocated by the enterprise } \\
\text { for waste disposal facilities construction, } \\
\text { thousand rub. per production unit }\end{array}$ & $\begin{array}{l}\mathrm{V}_{\text {ochs }}=\sum \mathrm{Z}_{\text {ochs }} \div \mathrm{q} \\
\sum \mathrm{Z}_{\text {ochs }}-\text { amount of funds, funds allocated by the en- } \\
\text { terprise for waste disposal facilities construction, } \\
\text { thousand rub. } \\
\mathrm{q}-\text { volume of manufactured products }\end{array}$ & 7,2 & 8,6 \\
\hline 8. & $\begin{array}{l}\mathrm{V}_{\text {zvs }} \\
\text { Volume of pollutants discharge in value } \\
\text { terms, tons/thousand rub. }\end{array}$ & $\begin{array}{l}\mathrm{V}_{\mathrm{zvs}}=\mathrm{M}_{\mathrm{zv}} \div \sum \mathrm{Z}_{\mathrm{tot}} \\
\text { где } \mathrm{M}_{\mathrm{zv}}-\text { volume of pollutants discharge, tons } \\
\sum \mathrm{Z}_{\mathrm{tot}}-\text { total value of costs for manufacturing and } \\
\text { sales of products }\end{array}$ & 0.0009 & 0.00084 \\
\hline 9. & $\begin{array}{l}\mathrm{INV}_{\text {ooo }} \\
\text { Sum of investments in the objects of envi- } \\
\text { ronmental protection, thousand rub. }\end{array}$ & $\begin{array}{l}I N V_{\text {ooo }}=\sum Z_{\text {oooc }} \\
\sum Z_{\text {ooc }}-\text { cost of investments in the objects of envi- } \\
\text { ronmental protection, thousand rub. }\end{array}$ & 4361 & 4768 \\
\hline 10. & $\begin{array}{l}\mathrm{INV}_{\mathrm{s}} \\
\text { Investments in the community, thousand } \\
\text { rub. }\end{array}$ & $\begin{array}{l}I N V_{\mathrm{s}}=\sum\left(\mathrm{Z}_{\mathrm{b}}+\mathrm{Z}_{\mathrm{oi}}+\mathrm{Z}_{\mathrm{fp}}\right) \\
\mathrm{Z}_{\mathrm{b}}=\text { charity costs, thousand rub. } \\
\mathrm{Z}_{\mathrm{o}}=\text { public infrastructure development costs, thou- } \\
\text { sand rub. } \\
\mathrm{Z}_{\mathrm{fsp}}=\text { social programs funding costs }\end{array}$ & 2984 & 3289 \\
\hline 11. & $\begin{array}{l}\mathrm{V}_{\text {pgkx }} \text { - volume of funds allocated for sup- } \\
\text { port of housing and utilities sector and ob- } \\
\text { jects of cultural and historical value, } \\
\text { rub./unit of production }\end{array}$ & $\begin{array}{l}\mathrm{V}_{\mathrm{pgkx}}=\mathrm{Z}_{\mathrm{pgkx}} \div \mathrm{q} \\
\mathrm{Z}_{\mathrm{pgkx}}-\text { sum of costs allocated for support of housing } \\
\text { and utilities sector and objects of cultural and his- } \\
\text { torical value, thousand rub. } \\
\mathrm{q}-\text { volume of manufactured products }\end{array}$ & 14,90 & 16,85 \\
\hline 12. & $\begin{array}{l}V_{\mathrm{ba}} \text { - volume of funds allocated for holding } \\
\text { charity events, rub./ unit of production }\end{array}$ & $\begin{array}{l}\mathrm{V}_{\mathrm{ba}}=3_{\mathrm{ba}} \div \mathrm{q} \\
\mathrm{Z}_{\mathrm{ba}}-\text { sum of costs allocated for holding charity } \\
\text { events, thousand rub. } \\
\mathrm{q}-\text { volume of manufactured products }\end{array}$ & 12,1 & 14,8 \\
\hline
\end{tabular}

Also analyzing this Table, one can see the increase in the amount of funds allocated by the enterprise for the purpose of environmentally safe production activity maintaining and for the construction of treatment facilities and the reduction of pollutants emission, water and wastes discharge. This fact indicates that after conducting management consulting the enterprise has fully utilized the available potential for environmental performance improvement. The data in the Table 1 indicate an effective solution of the most important social problems, ensuring the achievement of the goals set for the additional social security of the workers and the rational implementation of social policy. Thus, the amounts of investments into the environmental protection objects as well as investments into the community 
have increased by $9.3 \%$ and $10.2 \%$, respectively; the amounts of funds allocated to the support of socially unprotected strata of the population, to support of housing and communal services and cultural objects of historical significance, to support of socially significant events and charity events have increased by an average of $15 \%$.

The advantage of applying these key performance indicators is as follows: systematic approach to the analysis of activities, as the used indicators reflect key factors in increasing management efficiency; the analysis gives evaluation of the dynamics and changes in key indicators, making it possible to analyze both effective and unprofitable companies on the basis of the unified criteria; the methodology assumes calculation of various indicators including natural and value, qualitative and quantitative. This technique allows any organization to assess the real management efficiency of production and financial activity.

\section{Conclusions}

We now can conclude that the provision of professional consulting assistance in solving management problems significantly affects their quality, improves the skills of management personnel, improves information management, disseminates and introduces managerial innovations and scientific and practical knowledge. Using the proposed conceptual model of management consulting in the organizational structure, in conjunction with the basic approaches, methods, tools, models, methods and conditions, managers of enterprises will be more accessible to the process of determining the effectiveness of management consulting. When solving problems and issues in complex economic structures in the context of a systematic approach, it is necessary to create an appropriate system of criteria and indicators, which should correspond to the basic principles of reliability and relevance. To assess the effectiveness of management consulting, it is advisable to apply the KPI system, which provides an opportunity for a comprehensive assessment of the results of management consulting in qualitative and quantitative terms, both for the client organization and for the consultant. The proposed system of key performance indicators promotes attracting and retaining the consumer, increasing the professionalism of employees, increasing incomes and reducing costs. With the help of complex analysis, it is possible to realistically assess the effectiveness of management consulting, determine the best organizational forms, methods, technologies for managing specific objects to achieve a system-driven set economic results. The desired result can be achieved by conducting a project on management consulting based on the key principles of quality management and aimed at meeting the requirements of consumers and the benefits received by the client organization and consultant.

\section{References}

Antonchenko, N. G., \& Kalenskaya, N. V. (2014). Developing a methodology for assessing the efficacy of managerial decisions in entrepreneurial establishments. Life Science Journal, 11(7s).

Boeger, N., Murray, R., \& Villiers, C. (Eds.). (2008). Perspectives on corporate social responsibility. Edward Elgar Publishing.

Gorman, G. G., \& McCarthy, S. (2006). Business development support and knowledge-based businesses. The Journal of Technology Transfer, 31(1), 131-143.

Huning, S., Naumann, M., Bens, O., \& Hüttl, R. F. (2011). Transformations of modern infrastructure planning in rural regions: The case of water infrastructures in Brandenburg, Germany. European Planning Studies, 19(8), 1499-1516.

Ibatova, A.Z. (2017) The impact of the economy on teachers' work in the Russian Federation. International Journal of Applied Business and Economic Research, 15(21), 67-73.

Kalenskaya, N., \& Shafigullina, A. (2014). The invariance as a feature of business systems' infrastructural innovative development. Mediterranean Journal of Social Sciences, 5(18), 241. 
Klychova, G. S., Safiullin, L. N., \& Klychova, A. S. (2014a). Features of application of relevant approach in decision making to participate in tender for assessment of land. Mediterranean Journal of Social Sciences, 5(18), 183.

Klychova, G. S., Zakirova, A. R., Mukhamedzyanov, K. Z., \& Faskhutdinova, M. S. (2014b). Management reporting and its use for information ensuring of agriculture organization management. Mediterranean Journal of Social Sciences, 5(24), 104.

Klychova, G. S., Nizamutdinov, M. M., Safiullin, L. N., \& Mavlieva, L. M. (2014c). Priorities of agricultural credit cooperation development. Mediterranean Journal of Social Sciences, 5(18), 215.

Klychova, G. S., Fakhretdinova, E. N., Klychova, A. S., \& Antonova, N. V. (2015a). Development of accounting and financial reporting for small and medium-sized businesses in accordance with international financial reporting standards. Asian Social Science, 11(11), 318.

Klychova, G. S., Faizrakhmanov, D. I., Zakirova, A. R., \& Sadrieva, E. R. (2015b). Forecasting the development of horse breeding enterprises. Asian Social Science, 11(11), 302.

Klychova, G. S., Zakirova, A. R., Zakirov, Z. R., \& Valieva, G. R. (2015c). Management aspects of production cost accounting in horse breeding. Asian Social Science, 11(11), 308.

Klychova, G. S., Fakhretdinova, E. N., Klychova, A. S., \& Antonova, N. V. (2015d). Development of accounting and financial reporting for small and medium-sized businesses in accordance with international financial reporting standards. Asian Social Science, 11(11), 318-322.

Klychova, G., Zakirova, A., \& Kamilova, E. (2016). The methodological instruments of social audit in the agricultural companies development. International Business Management, 10(22), 5254-5260.

Klychova, G. S., Zakirova, A. R., Mukhamedzyanov, K. Z., Sadrieva, E. R., \& Klychova, A. S. (2017). Development of audit system for operations with fixed assets as a tool for efficiency improvement of social activity of the enterprise. Journal of Engineering and Applied Sciences, 12(19), 4966-4973.

Kolbina, A. D., \& Chumarina, G. R. (2016). Features of consulting development of Tatarstan Republic. International Business Management, 10(10), 1943-1945.

Lee, M. (2011). Key performance indicators for $\mathrm{PhD}$ education in biomedicine and health sciences. Turkish Journal of Biochemistry, 1(36), 60-62.

Rompho, N. (2011). Why the balanced scorecard fails in SMEs: A case study. International Journal of Business and Management, 6(11), 39.

Salimon, M., Bamgbade, J., Nathaniel, A \& Adekunle, T. (2017). Integrating technology acceptance model and organizational innovativeness in the adoption of mobile commerce. Management Science Letters , 7(10), 497-512.

Strelnik, E. U., Usanova, D. S., Khairullin, I. G., Shafigullina, G. I., \& Khairullina, K. T. (2017). Key performance indicators in internal control. Journal of Engineering and Applied Sciences, 12(19), 4899-4904.

Teixeira, C. P. (2013). Social capital in Europe. A three-step analysis. its structure, levels, individual and contextual determinants. Mediterranean Journal of Social Sciences, 4(9), 356.

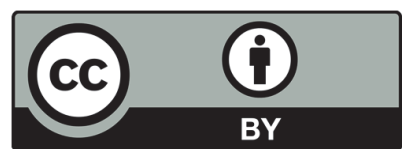

(C) 2018 by the authors; licensee Growing Science, Canada. This is an open access article distributed under the terms and conditions of the Creative Commons Attribution (CC-BY) license (http://creativecommons.org/licenses/by/4.0/). 